\title{
Lolium multiflorum seed quality analyzed by accredited laboratories in the Rio Grande do Sul State
}

\section{Caroline Huth $^{1^{*}(D)}$ Sidinei José Lopes ${ }^{1}$ Caren Alessandra Müller ${ }^{1}$ Cariane Pedroso da Rosa $^{2}$ (D) Fabrício Fuzzer de Andrade ${ }^{1}$ (D) Larissa Staggemeier dos Santos ${ }^{3}$ (D) Nilson Matheus Mattioni ${ }^{4}$ (D)}

${ }^{1}$ Programa de Pós-graduação em Agronomia, Universidade Federal de Santa Maria (UFSM), 97105-900, Santa Maria, RS, Brasil. E-mail: huth.caroline@yahoo.com.br. "Corresponding author.

${ }^{2}$ Programa de Pós-graduação em Agrobiologia, Universidade Federal de Santa Maria (UFSM), Santa Maria, RS, Brasil.

${ }^{3}$ Curso de Agronomia, Universidade Federal de Santa Maria (UFSM), Santa Maria, RS, Brasil.

${ }^{4}$ Departamento de Fitotecnia, Universidade Federal de Santa Maria (UFSM), Santa Maria, RS, Brasil.

ABSTRACT: The objective of this research was to carry out a survey, through the levels of physical purity, percentage of pure seeds, number of other seeds, and the physiological quality through germination, in the samples of ryegrass seeds analyzed in laboratories accredited by the Ministry of Agriculture, Livestock and Supply in Rio Grande do Sul. Data from 3959 ryegrass samples analyzed from the period 2014 to 2017 were compiled. Quality of the seeds was presented through the percentage of samples within the standards recommended for commercialization, for the variables germination, pure seeds, seeds of cultivated species, wild, noxious, tolerated and noxiously forbidden, in all factors, cultivar, region of origin, category and crop of seed production. Quality of the lots of ryegrass seeds, analyzed by the laboratories of Rio Grande do Sul, obtained in the harvest of 2013 the lowest percentage of lots approved for commercialization, 57.96\%, and the harvest of 2014, 2015 and 2016 with 89.60\% 91.39\% and 91.34\%, respectively. In regions where livestock predominates, the percentage of ryegrass seed lots approved for commercialization was lower.

Key words: ryegrass, seed production, germination, purity.

Qualidade de sementes de Lolium multiflorum analisadas pelos laboratórios credenciados no Estado do Rio Grande do Sul

RESUMO: O objetivo desta pesquisa foi realizar um levantamento, através dos níveis de pureza física, em percentagem de sementes puras, número de outras sementes, e qualidade fisiológica através da germinação, nas amostras de sementes de azevém analisadas nos laboratórios credenciados pelo Ministério da Agricultura, Pecuária e Abastecimento do Rio Grande do Sul. Foram compilados os dados de 3959 amostras de azevém, analisadas do periodo de 2014 a 2017. A qualidade das sementes foi apresentada através da porcentagem de amostras dentro dos padrões recomendados para comercialização, para as variáveis germinação, sementes puras, sementes de espécies cultivadas, silvestres, nocivas toleradas e nocivas proibidas, dentro dos fatores como cultivar, região de procedência, categoria e safra de produção da semente. A qualidade dos lotes de sementes de azevém, analisados pelos laboratórios do Rio Grande do Sul, obteve na safra de 2013 menor porcentagem de lotes aprovados para comercialização, 57,96\%, e as safras 2014, 2015 e 2016 com 89,60\%, 91,39\% e 91,34\%, respectivamente. Em regiões em que há predomino da pecuária a porcentagem de lotes de sementes de azevém aprovados para comercialização foi menor.

Palavras-chave: azevém, produção de sementes, germinação, pureza.

\section{INTRODUCTION}

The annual ryegrass (Lolium multiflorum L.) is one of the most important winter forages, which meets the food demand for cattle and sheep herds, presenting good nutritional quality, good potential of dry phytomass production and adaptability. In the southern region of Brazil, ryegrass is used in exclusive cultivation, intercropped with other grasses and legumes, sowed over natural pastures for improving them, or in crop-livestock integration systems, pasture areas, and later being differed for seed harvesting. (DE CONTO et al., 2011; FLORES et al., 2008; PEREIRA et al., 2008).

To maximize the potential of the property by diluting pasture production costs, dual-purpose ryegrass cultivation is frequent. Some researches showed that the production of seeds obtained 
from pasture areas and later differed to the seed collection results in lower seed productivity and low physiological quality, if differentiated management does not exist. (MEDEIROS e NABINGER, 2001; PASLAUSKI et al., 2014; TONETTO et al., 2011). This fact can result in the commercialization of seeds with low physical, genetic and health quality, with negative effects on the implantation of the crop and the increase of production costs. (SILVA, MAIA, MAIA, 2011). Moreover, it may lead to an irregular supply of quality seeds, inducing to an informal production system, that is, the sale of seeds produced outside the Sistema Nacional de Sementes e Mudas (National Seed and Seedling System of Brazil).

Studies about the quality of ryegrass seeds which were commercialized in the states of Paraná in 2006 (OHLSON, SOUZA, PANOBIANCO, 2008) and of Rio Grande do Sul in 1995 (FONSECA, MAIA, LUCCA-FILHO, 1999), showed that respectively $64 \%$ and $53 \%$ of the ryegrass samples presented a smaller percentage of germination than the minimum standard for commercialization of this species. In 2007, in Paraná, $100 \%$ of the ryegrass samples were above the germination standard (OHLSON, SOUZA, PANOBIANCO, 2008). However, from 2008 to 2010,50 to $100 \%$ of ryegrass samples were below the standard for commercialization in the pure seed parameter, depending on the evaluated year and the cultivar (OHLSON et al., 2011). Even if these studies do not cover a so expressive number of samples, they demonstrated the variability of quality ryegrass seeds production for commercialization and the need of information about the factors that affect the quality.

Given the above, it is demonstrated there are peaks of quality ryegrass seeds production for commercialization, and the importance of further information about which parameters may be contributing to the quality and; consequently, to the organization of the seed production chain of this crop. Thus, the aim of this research was to perform a survey, through physical purity levels, percentage of pure seeds, number of other seeds, and physiological quality through germination, in the ryegrass seed samples analyzed in laboratories accredited by the Ministério da Agricultura, Pecuária e Abastecimento (MAPA), which is the Ministry of Agriculture Livestock and Supply of Rio Grande do Sul, from 2014 to 2017.

\section{MATERIALS AND METHODS}

Data were compiled from 3959 samples of Lolium multiflorum seeds, analyzed from August
2014 to August 2017 by the MAPA-accredited Seed Analysis Laboratories of Rio Grande do Sul.

The quality of ryegrass seeds, from 2014 to 2017 , was presented through the percentage of samples within the recommended commercialization standards, according to the Normative Instruction number 25 (BRAZIL, 2005). It means they were approved for the variables germination $(G)$, pure seeds (P), seeds of cultivated species (ESPC), wild (SILV), noxious tolerated (NTOL) and noxious prohibited (NPRO), in all factors, cultivar, region of origin, category and the harvest of seed production. The minimum germination standards are $60 \%$ for Basic category and $70 \%$ for $\mathrm{C} 1, \mathrm{C} 2, \mathrm{~S} 1$ and $\mathrm{S} 2$; the minimum for pure seeds is $97 \%$ for all seed categories; The maximum tolerated number of ESPC and SILV seeds are 0 (Basic), $5(\mathrm{C} 1), 10(\mathrm{C} 2)$ and 15 (S1 and $\mathrm{S} 2$ ); NTOLs are maximum of 0 (Basic), 2 (C1), 5 (C2) and 10 (S1 and S2) seeds; for NPRO zero seeds are tolerated in all categories (BRAZIL, 2005). Statistical analyzes were performed using the software Action (ESTATCAMP, 2011) and Microsoft ${ }^{\circledR}$ Office Excel.

\section{RESULTS AND DISCUSSION}

Table 1 shows the percentage of ryegrass seed lots within the standard for commercialization, in the variables (G, P, ESPC, SILV, NTOL and NPRO) within the factors (harvest, category and cultivar). There is a lower percentage in all variables in the 2013 crop, with a smaller number of approved germinating lots, pure seeds and SILV (Table 1). The total number of samples approved for 2013 harvest was lower (57.96\%), followed by 2014 (89.60\%), 2015 and 2016 (91\%), demonstrating with this an improvement in the quality of ryegrass seed lots over the years.

For NPRO variable (Table 1), there is generally less reprobation of ryegrass lots in the harvests, categories and cultivars, except for INIA Titan, demonstrating the efficiency of good practices of conduction in the field and beneficiation for this variable.

Regarding the percentage of ryegrass seeds within the limit for commercialization in the categories (Table 1), Basic has the lowest total percentage, and in SILV and NTOL. Basic seed is a material obtained from the reproduction of genetic seed, performed in a way to ensure its genetic identity and varietal purity (BRAZIL, 2005). As it is genetic material for the production of the other categories, it has a higher physical quality requirement, explaining thus the highest reprobation of purity and other seeds.

In category C2 (Table 1), there is lower total percentage of approved lots $(9.26 \%)$, as well as in 
Table 1 - Percentage of ryegrass seed lots of 3959 samples, within the standard established for commercialization, in germination tests (G), pure seeds (P), number of seeds of cultivated species (ESPC), number of seeds of wild species (SILV), number of tolerated noxious species (NTOL) and number of prohibited noxious species (NPRO) within crops, category and cultivar, with respective number of samples $(\mathrm{N})$.

\begin{tabular}{|c|c|c|c|c|c|c|c|c|c|}
\hline & & G & $\mathrm{P}$ & ESPC & SILV & NTOL & NPRO & TOTAL & $\mathrm{N}$ \\
\hline \multirow{4}{*}{ HARVEST } & 2013 & 79.62 & 75.16 & 95.54 & 71.34 & 94.27 & 98.73 & 57.96 & 157 \\
\hline & 2014 & 95.47 & 97.37 & 98.35 & 95.96 & 99.02 & 99.69 & 89.60 & 1635 \\
\hline & 2015 & 97.34 & 97.92 & 98.71 & 97.42 & 97.42 & 99.28 & 91.39 & 1393 \\
\hline & 2016 & 97.29 & 99.22 & 100 & 95.22 & 97.80 & 99.61 & 91.34 & 774 \\
\hline \multirow{5}{*}{ CATEGORY } & BASIC & 96.55 & 89.66 & 100 & 27.59 & 55.17 & 100 & 17.24 & 29 \\
\hline & C1 & 94.44 & 97.22 & 100 & 97.22 & 100 & 100 & 94.44 & 36 \\
\hline & $\mathrm{C} 2$ & 81.48 & 70.37 & 11.11 & 98.15 & 96.30 & 98.15 & 9.26 & 54 \\
\hline & $\mathrm{S} 1$ & 96.24 & 95.14 & 99.89 & 92.60 & 97.90 & 99.89 & 87.07 & 905 \\
\hline & S2 & 96.01 & 98.19 & 99.90 & 96.80 & 98.50 & 99.39 & 92.13 & 2935 \\
\hline \multirow{14}{*}{ CULTIVAR } & Baqueano & 100 & 100 & 97.22 & 100 & 100 & 100 & 97.22 & 36 \\
\hline & BRS Integração & 0.00 & 66.67 & 100 & 33.33 & 66.67 & 100 & 0.00 & 3 \\
\hline & BRS Ponteio & 94.74 & 95.60 & 98.97 & 93.33 & 97.95 & 99.91 & 87.35 & 2340 \\
\hline & Comum & 100 & 90.00 & 100 & 80.00 & 90.00 & 100 & 80.00 & 10 \\
\hline & Eclipse & 100 & 100 & 100 & 100 & 100 & 100 & 100 & 10 \\
\hline & $\mathrm{F} A B C 1$ & 89.19 & 100 & 100 & 100 & 100 & 100 & 89.19 & 37 \\
\hline & Fepagro São Gabriel & 99.02 & 98.65 & 97.30 & 99.88 & 100 & 100 & 96.07 & 814 \\
\hline & INIA Bakarat & 50.00 & 100 & 100 & 100 & 75.00 & 100 & 50.00 & 4 \\
\hline & INIA Camaro & 100 & 100 & 100 & 100 & 100 & 100 & 100 & 8 \\
\hline & INIA Titan & 100 & 100 & 100 & 100 & 100 & 66.67 & 66.67 & 9 \\
\hline & LE 284 & 96.22 & 100 & 99.51 & 99.18 & 97.87 & 97.70 & 91.13 & 609 \\
\hline & Nibbio & 93.75 & 100 & 93.75 & 100 & 100 & 100 & 93.75 & 16 \\
\hline & Santa Maria & 100 & 96.15 & 100 & 30.77 & 57.69 & 100 & 19.23 & 26 \\
\hline & Winter Star & 100 & 100 & 97.30 & 100 & 91.89 & 97.30 & 89.19 & 37 \\
\hline
\end{tabular}

the variables: germination, purity and ESPC, drawing attention to the latter, with only $11 \%$ of approved samples. The quality of the "superior" categories is of great relevance, as they are responsible for the production of the other categories. Category C2 will originate categories $\mathrm{S} 1$ or $\mathrm{S} 2$ when multiplied in the field, and the contamination caused by other seeds will spread in the next generations, if there is not a control with conduction management practices since the production fields to the harvesting procedures and appropriate beneficiation.

Categories C1, S1 and S2 (Table 1) present a high percentage of seeds within the limits for commercialization in all variables. The total percentage of non-standard lots for sale in categories $\mathrm{S} 1$ and $\mathrm{S} 2$ is high, at $87.07 \%$ and $93.13 \%$ respectively.

It is observed that the number of samples (Table 1) of ryegrass seeds in categories S1 and S2 is predominant in relation to the other categories. TERNUS (2017), who evaluated the quality of seeds coming from the trade inspection of annual ryegrass seed in the state of Santa Catarina, in the years 2013-
2015, also reported a higher number of seed samples in categories S1 and S2, being the latter in greater numbers. As categories S1 and S2 are produced outside the certification process and resulting from the reproduction of $\mathrm{S} 1$ seed, first certified seed (C1), second generation $(\mathrm{C} 2)$, from basic seed or genetic seed, they are lower categories, compared to the Basic, Genetic, C1 and C2 categories. Thus, they are produced on a larger scale.

Regarding ryegrass cultivars (Table 1), there is a predominance of cultivars of Brazilian commercial origin (BRS Ponteio and Fepagro São Gabriel), followed by Uruguay (LE 284). Besides, there is a predominance of diploid cultivars in the studied samples. The tetraploid cultivars (AYALA, et al. 2010; INASE, 2018) are Baqueano, INIA Titan and Winter Star, which present high physiological quality, being $100 \%$ of the lots approved for germination (Table 1).

The ryegrass exists in nature as a diploid plant $(2 \mathrm{n}=2 \mathrm{x}=14$ chromosomes $)$, but there are tetraploid cultivars $(2 \mathrm{n}=4 \mathrm{x}=28$ chromosomes $)$ originated from plant genetic improvement through 
the chromosomal duplication technique. According to FARINATTI et al. (2006) and CARVALHO et al. (2010), tetraploid ryegrass plants have broader and darker leaves, smaller but larger tillers, higher total forage mass production, longer vegetative cycle, lower dry matter content and larger seeds, being able to produce better quality seeds.

The ryegrass cultivar of Embrapa, BRS Ponteio, with $87.35 \%$ of the approved lots (Table 1), is in larger number of samples, possibly being the preferred of the producers. Therefore, it is recommended for cultivation in Rio Grande do Sul, Brazil, because it presents high production potential, longer production cycle and better distribution of forage production throughout the growing season, as well as higher production precocity (MONTARDO and MITTELMANN, 2009).

The cultivars (Table 1) Eclipse and INIA Camaro presented $100 \%$ of the samples within the limits for commercialization, but a small number of samples, 10 and 8, respectively. BRS Integração (Table 1) presented $0 \%$ of ryegrass samples at the standard limit for commercialization, but of only 3 samples for this cultivar; besides, the percentage within the standard for purity, SILV and NTOL were low. The low number of samples of BRS Integração may be due to the recent release in the market. BRS Ponteio, with the largest number of samples, was the first ryegrass cultivar developed by EMBRAPA, launched in 2007 (BRASIL, 2018).

Cultivars INIA Bakarat, INIA Titan and Santa Maria (Table 1) presented the lowest number of lots approved for commercialization, with higher reprobation in other seeds by number, in cultivar Santa Maria in SILV and NTOL and Common in SILV.

Table 2 shows the percentage of ryegrass seed lots within the standard for commercialization, in the variables (G, P, ESPC, SILV, NTOL and NPRO) within the provenances of the lots. The regions of Rio Grande do Sul State of origin of the lots cover both seed and livestock production regions, which seed can be a byproduct.

The sites with the largest number of samples, above 200, in the studied four years (Table 2) are Tupanciretã, Santa Barbara do Sul, Ijuí, Uruguay, Pedras Altas, Santo Ângelo and Cruz Alta; above 100 samples, Julio de Castilhos, Passo Fundo, Cachoeira do Sul, Augusto Pestana, Pelotas and Capinzal; and number of samples above 50, are Santa Rosa, Carazinho, São Lourenço do Sul, Coronel Barros, Caçapava do Sul, Marau and Realeza.

Of the 38 locations, those with $100 \%$ of the lots within the established standards for commercialization are Água Santa, Boa Vista do Incra, Cachoeira do Sul, Capinzal, Carazinho, Catuípe, Coronel Barros, Coxilha, Passo Fundo, Realeza São Luiz Gonzaga, Tapera and Vacaria.

Concerning other seeds by number, there is a higher percentage of NPRO-approved ryegrass lots (Table 2), except for Marau, Pedras Altas and Uruguay. There is a higher reprobation of ryegrass lots in germination (Table 2), with lower percentages of non-standard lots for commercialization in the locations of Caçapava do Sul (69\%), Capão do Leão (50\%), Humaitá (46). \%), Pelotas (76), Santa Rosa (79) and São Gabriel (68), as well as the total percentage of samples approved in these origins were smaller, adding Bagé (75.86\%), Pedras Altas (66.33\%). and Uruguaiana $(70 \%)$. Thus, demonstrating that in typical livestock regions, ryegrass lots present inferior quality compared to typical seed producing regions such as Passo Fundo, Ijuí, Tapera and Tupanciretã.

Pedras Altas, as well as Caçapava do Sul, are predominant regions of livestock (IBGE, 2017), and since in typical livestock regions seed production is a secondary activity, considered as a residue of the forage surplus, it results in seeds of lower quality. Production of seeds obtained from pasture areas and later differed to seed harvesting, may result in lower physiological quality of seeds. Factors that may be related to seed yield and quality are the management of nutrient doses, height, number and time of cut and harvest time (spikelet maturity). These factors affected the weight of one thousand seeds, germination and vigor, health and seed productivity (MEDEIROS and NABINGER, 2001; PASLAUSKI et al., 2014; TONETTO et al., 2011).

Conversely, results reported by FONSÊCA, MAIA and LUCCA-FILHO (1999), who analyzed the quality of annual ryegrass seeds produced in Rio Grande do Sul, in the 1995 harvest, from 27 cities, totalizing 226 samples, showed that only $54 \%$ of the samples were within the standard for purity due to the large variability of inert material, and $81 \%$ of the samples were within the standard limit for germination. Thus, the results showed an improvement in the last years regarding the ryegrass seed quality in Rio Grande do Sul.

Moreover, the results showed there is a high percentage of seeds approved for sale in the state, which goes against the low utilization rate of ryegrass seeds, $33 \%$ in the $2014 / 2015$ crop, according to ABRASEM (2016). It demonstrated that this low utilization is not due to low quality seed supply, but possibly to a lack of producer awareness about benefits of using certified seed. 
Table 2 - Percentage of ryegrass seed lots of 3959 samples, within the standard established for commercialization, in germination tests (G), pure seeds (P), number of seeds of cultivated species (ESPC), number of seeds of wild species (SILV), number of tolerated harmful species (NTOL) and number of prohibited harmful species (NPRO), in the source of origin, with the respective number of samples $(\mathrm{N})$.

\begin{tabular}{|c|c|c|c|c|c|c|c|c|}
\hline Provenances & $\mathrm{G} \%$ & $\mathrm{P} \%$ & ESPC & SILV & NTOL & NPRO & TOTAL & $\mathrm{N}$ \\
\hline Água Santa & 100 & 100 & 100 & 100 & 100 & 100 & 100 & 26 \\
\hline Alegrete & 100 & 100 & 100 & 75.00 & 100 & 100 & 75.00 & 8 \\
\hline Argentina & 100 & 100 & 97.30 & 100 & 83.78 & 100 & 81.08 & 37 \\
\hline Augusto Pestana & 97.73 & 95.45 & 97.73 & 100 & 98.48 & 100 & 90.91 & 132 \\
\hline Bagé & 100 & 98.85 & 100 & 79.31 & 87.36 & 100 & 75.86 & 87 \\
\hline Boa Vista do Incra & 100 & 100 & 100 & 100 & 100 & 100 & 100 & 15 \\
\hline Caçapava do Sul & 69.64 & 67.86 & 80.36 & 91.07 & 80.36 & 100 & 25.00 & 56 \\
\hline Cachoeira do Sul & 100 & 100 & 100 & 100 & 100 & 100 & 100 & 135 \\
\hline Capão do Leão & 50.00 & 100 & 100 & 50.00 & 50.00 & 100 & 50.00 & 2 \\
\hline Capinzal & 100 & 100 & 100 & 100 & 100 & 100 & 100 & 101 \\
\hline Carazinho & 100 & 100 & 100 & 100 & 100 & 100 & 100 & 78 \\
\hline Castro & 86.84 & 100 & 97.37 & 100 & 100 & 100 & 86.84 & 38 \\
\hline Catuípe & 100 & 100 & 100 & 100 & 100 & 100 & 100 & 6 \\
\hline Coronel Barros & 100 & 100 & 100 & 100 & 100 & 100 & 100 & 77 \\
\hline Coxilha & 100 & 100 & 100 & 100 & 100 & 100 & 100 & 5 \\
\hline Cruz Alta & 100 & 99.56 & 100 & 100 & 99.56 & 100 & 99.13 & 229 \\
\hline Giruá & 92.31 & 92.31 & 84.62 & 100 & 100 & 100 & 84.62 & 26 \\
\hline Humaitá & 46.67 & 93.33 & 100 & 100 & 100 & 100 & 40.00 & 15 \\
\hline Ijuí & 96.15 & 96.70 & 98.63 & 99.73 & 99.73 & 100 & 93.96 & 364 \\
\hline Júlio de Castilhos & 88.37 & 97.09 & 100 & 99.42 & 100 & 100 & 84.88 & 172 \\
\hline Marau & 96.43 & 96.43 & 89.29 & 100 & 96.43 & 98.21 & 87.50 & 56 \\
\hline Passo Fundo & 100 & 100 & 100 & 100 & 100 & 100 & 100 & 155 \\
\hline Pedras Altas & 97.31 & 91.92 & 100 & 67.00 & 95.29 & 99.66 & 66.33 & 297 \\
\hline Pejuçara & 100 & 100 & 91.30 & 100 & 100 & 100 & 91.30 & 23 \\
\hline Pelotas & 76.92 & 66.35 & 100 & 58.65 & 92.31 & 100 & 51.92 & 104 \\
\hline Pinhalzinho & 90.00 & 100 & 100 & 100 & 100 & 100 & 90.00 & 20 \\
\hline Realeza & 100 & 100 & 100 & 100 & 100 & 100 & 100 & 53 \\
\hline Santa Bárbara do Sul & 99.43 & 99.72 & 97.44 & 100 & 100 & 100 & 97.44 & 352 \\
\hline Santa Rosa & 79.52 & 97.59 & 100 & 98.80 & 98.80 & 100 & 79.52 & 83 \\
\hline Santo Ângelo & 99.27 & 99.64 & 99.27 & 100 & 99.64 & 100 & 98.54 & 274 \\
\hline São Gabriel & 68.00 & 92.00 & 100 & 92.00 & 96.00 & 100 & 60.00 & 25 \\
\hline São Lourenço do Sul & 87.18 & 100 & 94.87 & 91.03 & 91.03 & 100 & 82.05 & 78 \\
\hline São Luiz Gonzaga & 100 & 100 & 100 & 100 & 100 & 100 & 100 & 10 \\
\hline Tapera & 100 & 100 & 100 & 100 & 100 & 100 & 100 & 20 \\
\hline Tupanciretã & 97.42 & 99.78 & 100 & 100 & 100 & 100 & 97.20 & 465 \\
\hline Uruguay & 97.74 & 100 & 98.71 & 98.39 & 96.45 & 94.19 & 87.42 & 310 \\
\hline Uruguaiana & 100 & 70.00 & 100 & 100 & 100 & 100 & 70.00 & 10 \\
\hline Vacaria & 100 & 100 & 100 & 100 & 100 & 100 & 100 & 15 \\
\hline
\end{tabular}

\section{CONCLUSION}

From 2013 to 2016 harvest, there was an improvement in the quality of ryegrass seed lots, analyzed by the laboratories of Rio Grande do Sul, where the 2013 harvest obtained a lower percentage of approved for sale lots, 57.96\%, while the 2014, 2015 and 2016 harvests obtained $89.60 \%, 91.39 \%$ and $91.34 \%$, respectively.
The largest number of ryegrass samples analyzed by the laboratories of the state of Rio Grande do Sul comes from that state, as well as there is predominance of diploid cultivars.

In cities of the states where there is a predominance of livestock activity, the percentage of ryegrass seed lots approved for commercialization was lower. 


\section{ACKNOWLEDGEMENTS}

This study was financed by the Conselho Nacional de Desenvolvimento Científico e Tecnológico (CNPq) and the Coordenação de Aperfeiçoamento de Pessoal de Nível Superior Brasil (CAPES) - Finance Code 001.

\section{DECLARATION OF CONFLICT OF INTERESTS}

The authors declare no conflict of interest. The founding sponsors had no role in the design of the study; in the collection, analyses, or interpretation of data; in the writing of the manuscript, and in the decision to publish the results.

\section{AUTHORS' CONTRIBUTIONS}

All authors contributed equally for the conception and writing of the manuscript. All authors critically revised the manuscript and approved of the final version.

\section{REFERENCES}

ASSOCIAÇÃO BRASILEIRA DE SEMENTES E MUDAS - ABRASEM. Anuário 2016. Brasília, DF, 2016. 124p. Available from: <http://www.abrasem.com.br/wp-content/ uploads/2013/09/Anuario_ABRASEM_2016_SITE.pdf.>. Accessed: Sep. 10, 2017.

AYALA, W. et al. Forrajeras. Catálogo de Cultivares 2010. Instituto Nacional de Investigación Agropecuária- INIA, Uruguai, 130 p.2010. Available from: <http://www.inia.uy/Publicaciones/ Documentos\%20compartidos/18429300810155513.pdf $>$. Accessed: Nov. 22, 2018

BRASIL. Ministério da Agricultura, Pecuária e Abastecimento - MAPA. Registro Nacional de Cultivares - RNC. 2018. Brasil. Available from: <http://sistemas.agricultura.gov.br/snpc/ cultivarweb/cultivares_registradas.php>. Accessed: Nov. 22, 2018.

BRASIL. Ministério da Agricultura, Pecuária e Abastecimento. Instrução Normativa $\mathbf{n}^{\mathbf{0}} \mathbf{2 5}$, de 16 de dezembro de 2005. Brasília, de 20 de dezembro de 2005. Seção 1, p 18-26. Available from: <http:// www.agricultura.gov.br/assuntos/insumos-agropecuarios/insumosagricolas/sementes-e-mudas/legislacao $>$. Accessed: Dec. 01, 2016.

CARVAlHO, P. C. de F. et al. Temperate Climate Forages Forage Plants. Viçosa-MG: UFV, 2010. Chap. 16. Available from: $<$ http://www.ufrgs.br/gpep/documents/capitulos/Forrageiras\%20 de\%20clima\%20temperado.pdf>. Accessed: Nov. 27, 2018.

DE CONTO, L. et al. Annual Ryegrass (Lolium multiflorum LAM.)-Ruminant relation. Archivos de Zootecnia, Córdoba, ES, v.60, p.41-54, 2011. Available from: <http://www.uco.es/organiza/ servicios/publica/az/php/img/web/09_11_46_2072REVISIONRel acaoDeConto.pdf $>$. Accessed: Jun. 05, 2017.

ESTATCAMP. Action: version 2.0. General public license. São Carlos: Estatcamp, 2011.

FARINATTI, L. H. E. et al. Evaluation of different ryegrass cultivars on calf performance. Embrapa Clima Temperado, Document 166, n.3-16. 2006. Available from: <www.cpact. embrapa.br/publicacoes/downloand/documentos/documento_166/ PDFs/3/3- 16.pdf>. Accessed: Nov. 01, 2018.

FLORES, R. et al. Forage production of annual ryegrass populations in the state of Rio Grande do Sul, Brazil. Revista Brasileira de Zootecnia, Viçosa, MG, v.37, p.1168-1175, 2008. Available from: $<$ http://www.scielo.br/scielo.php?script=sci artte xt\&pid=S1516-35982008000700005>. Accessed: Nov. 07, 2018. doi: 10.1590/S1516-35982008000700005.

FONSECA, M. G.; MAIA, M. S.; LUCCA FILHO, O. A. Quality evaluation of annual ryegrass (Lolium multiflorum Lam.) seeds produced in Rio Grande do Sul. Revista Brasileira de Sementes, Brasília, v.21, n.1, p.101-106, 1999.

IBGE. Instituto Brasileiro de Geografia e Estatística. Censo Agro 2017: Resultados Preliminares [do] Instituto Brasileiro de Estatística. Rio Grande do Sul: IBGE. Nov. 2017. Available from: <https://censos.ibge.gov.br/agro/2017/resultados-censoagro-2017.html>. Accessed: Nov. 22, 2018.

INASE. Instituto Nacional de Semillas. Ministerio de Ganadería, Agricultura y Pesca. Uruguay, 2018. Available from: <https:// www.inase.uy/>. Accessed: Nov. 22, 2018.

MEDEIROS, R.B.; NABINGER, C. Annual ryegrass seed and forage yield in response to nitrogen rates and cutting regimes. Revista Brasileira de Sementes, v.23, n.2, p.245254, 2001. Available from: <https://www.researchgate.net/ publication/287943562 Rendimento de sementes e forragem de_azevem-anual_em_resposta_a_doses_de_nitrogenio_e_ regimes de corte>. Accessed: Nov. 07, 2018. doi: 10.17801/01013122/rbs.v23n2p245-254.

MONTARDO, D. P.; MITTELMANN, A. Evaluation of BRS Ponteio ryegrass cultivar in the Campaign Region of Rio Grande do Sul. Embrapa Pecuária Sul, Bagé, RS, Technical release 68, november 2009. Available from: <https://ainfo. cnptia.embrapa.br/digital/bitstream/item/131709/1/CO68.pdf $>$. Accessed: Nov. 07, 2018.

OHLSON, O. C. et al. Exploratory data analysis: quality of ryegrass seeds commercialized in Paraná state. Informativo ABRATES, Londrina, v.21, n.3, p.47-51, 2011

OHLSON, O. C.; SOUZA, C. R.; PANOBIANCO, M. Quality survey of ryegrass seeds commercialized in the state of Paraná. Informativo ABRATES, Londrina, v.18, p.18-22, 2008.

PASLAUSKI, B. M. C. et al. Productions and physiological seeds quality of ryegrass submited to cuts and harvest times. Revista trópica: Ciências Agrárias e Biológicas, Chapadinha, MA, v.09, n.01, p.01-13, 2014. Available from: <http://www. periodicoseletronicos.ufma.br/index.php/ccaatropica/article/ view/1142>. Accessed: Dec. 20, 2017.

PEREIRA, A. V. et al. Agronomic behaviour of annual ryegrass (Lolium multiflorum L.) populations for winter cropping in Southeast Region of Brazil. Ciência e Agrotecnologia, Lavras, MG, v.32, p.567-572, 2008. Available from: $<$ http://www.scielo.br/ pdf/cagro/v32n2/34.pdf>. Accessed: Apr. 10, 2016. doi: 10.1590/ S1413-70542008000200034

SILVA, G. M. da; MAIA, Melissa. B.; MAIA, Manoel de S. Quality of Temperate Climate Forage Seeds. Documentos 119. Embrapa 
Pecuária Sul. Bagé, RS, 19p., dez. 2011. Available from: <https:// ainfo.cnptia.embrapa.br/digital/bitstream/item/61500/1/DT-119. pdf>. Accessed: Jun. 07, 2017.

TERNUS, et al. Quality of Lolium multiflorum tetraploides seeds marketed in Santa Catarina. Revista Verde de Agroecologia e Desenvolvimento Sustentável, v.12, n.1, p.711. 2017. Available from: <https://www.gvaa.com.br/revista/
index.php/RVADS/article/view/4630>. Accessed: Oct. 27, 2018. doi: $10.18378 /$ rvads.v12i1.4630.

TONETTO, C. J. et al. Production and bromatological composition of ryegrass diploid and tetraploid genotypes. Zootecnia Tropical, Venezuela, v.29, p.169-178, 2011. Available from: <http://www.bioline.org.br/pdf?zt11014>. Accessed: Aug. 30, 2018. 